\title{
Ontogenetic Changes in the Rates of Protein Synthesis and Leucine Oxidation during Fetal Life
}

\author{
JAN M. KENNAUGH, ALAN W. BELL, CECILIA TENG, GIACOMO MESCHIA, AND \\ FREDERICK C. BATTAGLIA \\ Division of Perinatal Medicine, Departments of Pediatrics and Physiology, University of Colorado School of \\ Medicine, Denver, Colorado 80262
}

\begin{abstract}
Studies of fetal leucine metabolism and protein synthetic rate, using $1-\left(11^{14}\right)$ leucine as tracer, were carried out in 12 pregnant ewes at midgestation and compared with similar studies in late gestation. The disposal rate of fetal plasma leucine ranged between 3.07 and 9.06 $\mu \mathrm{mol} / \mathrm{min}$ and was correlated $(r=0.89)$ to fetal dry weight. The fluxes to $\mathrm{CO}_{2}$ excretion and to protein synthesis were $18.6 \pm 2.6$ and $37.2 \pm 2.6 \%$ of disposal rate, respectively. The flux of leucine molecules into the placenta was relatively large and correlated to the placental/fetal dry weight ratio $(r=0.84)$. The mean fractional protein synthetic rate was $0.216 \pm 0.01 \mathrm{day}^{-1}$. Comparison with late gestation data showed that fractional protein synthetic rate is inversely correlated $(r=-0.87)$ to gestational age and that fetal protein synthetic rate $\left(\mathrm{PR}_{s}, \mathrm{~g} /\right.$ day $)$ is related to fetal dry weight $(\mathrm{DW}, \mathrm{g})$ by the allometric equation: $\log \mathrm{PR}_{\mathrm{s}}=-\mathbf{0 . 5 0 3}+\mathbf{0 . 7 5 4} \log \mathrm{DW}$
\end{abstract}

The 0.754 exponent is similar to the exponent relating fetal oxygen consumption to dry weight $(0.729)$. This indicates that protein synthesis and energy metabolism per g dry weight decrease during fetal growth at approximately the same rate so that the protein synthesis/oxygen consumption ratio tends to remain constant. (Pediatr Res 22:688-692, 1987)

\section{Abbreviations}

a, umbilical arterial blood

d, days

DR, fetal disposal rate of leucine

DW, fetal dry weight

f, umbilical flow

GA, gestational age

$\mathbf{K}_{\mathrm{F}}$, fractional rate constant defining the time course of free leucine plasma specific activity

$K_{G}$, fractional growth rate of fetal dry weight

$\mathrm{KIC}$, ketoisocaproic acid

$K_{s}$, fractional fetal protein synthetic rate

$\mathrm{Leu}_{\mathrm{PR}}$, amount of leucine in fetal proteins

$\mathrm{Leu}_{\mathrm{R}_{\mathrm{s}}}$, flux of fetal plasma leucine into fetal protein synthesis

$\operatorname{Lys}_{\mathrm{R}_{\mathrm{s}}}$, flux of fetal plasma lysine into fetal protein synthesis PR, fetal proteins

Reccived May 26, 1987; accepted July 30, 1987

Correspondence and reprint requests Frederick C. Battaglia, M.D., Division of Perinatal Medicine, Box B-199, University of Colorado Health Sciences Center 4200 East Ninth Avenue, Denver. CO 80262.

Supported by NIH Program Grant HD-00781 and NIH Project Grant HD01866. J.M.K. was supported by Training Grant HD-07186. A.W.B. was on leave from the School of Agriculture, La Trobe University. Bundoora. Victoria 3083. Australia.
$P_{\mathrm{S}}$, fetal protein synthesis rate $r$, tracer leucine infusion rate $\mathbf{r}_{\mathrm{CO}_{2}}$, excretion rate of ${ }^{14} \mathrm{CO}_{2}$ into placenta from umbilical circulation

$R_{0 x}$, leucine decarboxylation rate

$\mathbf{R}_{\mathrm{p}, \mathrm{f}}$, flux of fetal leucine into placenta

$\mathrm{SA}$, specific activity of arterial free plasma leucine at steady state

$\mathrm{SA}_{1}$, specific activity of arterial free plasma leucine at time $t$

$\mathrm{SA}_{\mathrm{PR}}$, specific activity of leucine in fetal proteins

$v$, umbilical venous blood

$\dot{\mathrm{V}}_{\mathrm{O}_{2}}$, fetal oxygen uptake

IV, intravenous

PCS, phase combining system

GA, gestational age

Studies of amino acid metabolism in fetal sheep have been limited to late gestation and do not provide an adequate foundation for ontogenetic studies $(1-3)$. The importance of extending knowledge of amino acid metabolism from late to mid gestation is suggested by striking differences in fetal body composition, growth rate and oxygen requirements and in the placental/fetal mass ratio between these two stages of development $(4,5)$.

The present study applies tracer methodology to the investigation of fetal leucine metabolism at midgestation (73-88 days), a time when the fetus is only $5-10 \%$ of its birth weight. We focused attention on the essential amino acid leucine for two reasons: 1) it has dual importance as a constituent of body proteins and as a substrate of oxidative metabolism, and 2) the new information is directly comparable with results recently obtained by us in late gestation using similar techniques and data analysis (6). The study aims at providing the first description of the allometric relationships which pertain during fetal life for body size, metabolic rate, and whole-body protein synthesis.

\section{METHODS}

Biologic preparation. Twelve pregnant, Columbia-Rambouillet crossbred ewes with gestations of 73-88 days were studied. On the day of surgery the sheep were sedated with IV pentobarbital and given spinal anesthesia (6 mg pontocaine, $10 \%$ glucose). Streptomycin $(1 \mathrm{~g})$ was administered intramuscularly. Polyvinyl catheters were placed in the uterine vein draining the pregnant uterine horn, the maternal femoral artery, and the amniotic 688 
placed by visualizing the vessels coursing inside the uterus along the lesser curvature of the pregnant horn through a small incision in the greater curvature. Using microsurgical techniques and operating telescopes, small cotyledonary branches of the umbilical vein and antery were cannulated with the tips placed $2-3 \mathrm{~cm}$ into the major vessels. In twin pregnancies a fetal infusion catheter was placed into the other main umbilical vein or into the fetal femoral vein. In singleton pregnancies a fetal infusion catheter was placed in an umbilical venous branch in the nonpregnancy horn. These techniques for catheterization of the mid gestation fetal lamb have been previously described in detail (5). All catheters were tunneled subcutaneously to a plastic pouch fixed to the ewe's flank and flushed daily with heparinized saline (10) $\mathrm{U}$ heparin $\cdot \mathrm{ml}^{-1}$ for maternal catheters and $33 \mathrm{U}$ heparin. $\mathrm{ml}^{-1}$ for fetal catheters). Ampicillin $(250 \mathrm{mg}$ ) was administered into the amniotic cavity at surgery and on days 2 and 4 postoperatively.

Experimental procedure. After surgery the animals were housed in individual crates and allowed ad libitum access to alfalfa pellets and water. The studies were conducted 3-9 days postoperatively when the ewes were consuming adequate quantitics of food $\left(800-1600 \mathrm{~g} \cdot \mathrm{day}^{\prime}\right)$ and water. $A$ constant infusion of $\left.{ }^{3} \mathrm{H}_{2} \mathrm{O}\right)\left(1.0 \mu(\mathrm{i} / \mathrm{min})\right.$ and $1 .-\left[11^{14}(\mathrm{C}] \mathrm{leucine}(0.12 \mu(\mathrm{i} / \mathrm{min})\right.$ dissolved in saline was administered to the fetus through the venous infusion catheter. Fetal arterial samples were withdrawn serially beginning at $15 \mathrm{~min}$ until $240 \mathrm{~min}$ after starting the infusion and used for measurement of leucine specific activity. After isotopic plateau was reached, blood samples were simultaneously taken from the umbilical vein and artery and the uterine vein and maternal artery at $150,180,210$, and $240 \mathrm{~min}$. The samples were analyzed for oxygen content, amino acid concentrations. $\left.{ }^{3} \mathrm{H}, \mathrm{O}\right) .{ }^{1.4} \mathrm{C}(\mathrm{O}$ and hematocrit. Blood samples for separate analysis of lactate plasma $1-\left[1-^{14} \mathrm{C}\right]$ leucine and tracee leucine were withdrawn at the same time from the fetal arterial catheter alone. The volume of fetal blood withdrawn $(2.3 \mathrm{ml})$ was replaced immediately after each sampling with a transfusion of fetal blood.

At the end of the study the ewe and fetus were killed with rapid IV injection of " $1-61$ cuthanasia solution. The total infusion time was noted and the infusate saved for analysis of ${ }^{3} \mathrm{H}_{2} \mathrm{O}$ and $\mathrm{I}-\left[1-{ }^{14} \mathrm{C}\right]$ leucine radioactivity. The ${ }^{14} \mathrm{C}$ infusate radioactivity infusion rate and time were used to calculate the total amount of I. $-\left[1-{ }^{14} \mathrm{C}\right]$ leucine administered to the fetus.

At autopsy the pregnant uterus, placental cotyledons. and study fetus were separated and weighed. The placenta and fetus were homogenized separately and frozen at $-70^{\circ} \mathrm{C}$ for later analysis.

Analytical methods. Fetal and maternal plasma ${ }^{3} \mathrm{H}_{2} \mathrm{O}$ activities were counted in a Packard Tri-Carb 460 C liquid scintillation counter after solubilization in Protosol and mixture with $15 \mathrm{ml}$ of PCS ( $\Lambda$ mersham) liquid scintillation cocktail. Plasma ${ }^{3} \mathrm{H}_{2} \mathrm{O}$ concentrations were converted to whole blood concentrations using the hematocrit data, as previously described (7).

Fetal and maternal blood samples for oxygen content were drawn into heparinized glass capillary tubes. Blood samples for lactate analysis were drawn into syringes encased in ice. Hemoglobin concentration and oxygen saturation were measured immediately with an automatic. direct reading photometer (Radiometer (OSM-2), and blood oxygen content calculated. Blood for lactate analysis was deproteinized with perchloric acid. The filtrate was stored at -7$)^{\circ}\left({ }^{\circ}\right.$ and subsequently analyzed by means of a lactate dehydrogenase method (5).

Fetal arterial blood samples for amino acid analysis were immediately centrifuged at $5^{\circ} \mathrm{C}$ for $15 \mathrm{~min}$, and the plasma fro $\%$ en at $-70^{\circ}$ (. Plasma was deproteinized by adding $15 \%$ sulfosalicylic acid, the supernate collected, and the leucine concentration determined in an aliquot of the supernatant with a JEOL -200A amino acid analyzer using a norleucine internal standard. Another aliquot of the supernatant was used to determine the $1-\left[1-1^{1.4} \mathrm{C}\right] \mathrm{leucine}$ concentration with a JEOL-6 AH amino acid analyzer. The JEOL -6 AH analyzer was adapted with a short I. CR-2 resin column fixed at a temperature of $41^{\circ}\left({ }^{\circ}\right.$ as described previously (6). Sodium citrate buffer (ph 4.25 ) was used for elution and fractions collected at $1(0$-min intervals. We have shown that ${ }^{1+4}$-leucine is effectively separated from other ${ }^{14}$ ('-labeled compounds with these column conditions (6). The sample was mixed with PCS scintillation fluid and the radioaclivity measured in a Packard Tri-Carb 460 C liquid scintillation counter with internal quench correction.

Fetal and placental tissue homogenates were acid hydrolyed as previously described (8). After hydrolysis the samples were dried and redissolved in buffer ( $\mathrm{pH}_{2} 2.2$ ) for measurements of leucine and tracer leucine content (6).

Calculations. Umbilical flow (f) was measured by the steadystate transplacental diffusion method using tritiated water as the test molecule (9).

l.cucine fluves. The DR ( $\mu \mathrm{mol} / \mathrm{min})$ was calculated using the $\mathrm{r}(\mathrm{I}) \mathrm{PM} / \mathrm{min})$, and the $\mathrm{S} \wedge(\mathrm{DPM} / \mu \mathrm{mol})$ :

$$
D R=r / S A
$$

As shown in a previous study (6). this disposal rate hats three major components: the $R_{w}(\mu \mathrm{mol} / \mathrm{min})$, the $\mathrm{I} . \mathrm{cu}_{\mathrm{R}_{\mathrm{V}}}(\mu \mathrm{mol} / \mathrm{min})$. and the $\mathrm{R}_{\mathrm{p} . \mathrm{i}}(\mu \mathrm{mol} / \mathrm{min})$.

The $\mathrm{R}_{\text {on }}$ rate was calculated using the exeretion rate of ${ }^{4} \mathrm{CO}$, into the $\mathrm{r}_{\left(\mathrm{C}_{2}\right.}(\mu \mathrm{mol} / \mathrm{min})$ and $\mathrm{SA}$ :

$$
R_{i n}=r_{(0)} / S \Lambda
$$

The $r_{(0)}$, rate was measured by application of the rick principle to the umbilical exeretion of ${ }^{1+}\left(\mathrm{C} \mathrm{O}_{2}(6)\right.$ :

$$
r_{(0)}=f\left({ }^{14} \mathrm{CO}_{2-1}-{ }^{14} \mathrm{CO}_{2}\right)
$$

where ${ }^{1+} \mathrm{CO}_{2}$ and ${ }^{14} \mathrm{CO}$, represent the concentration of ${ }^{14} \mathrm{CO}$. $(\mathrm{DPM} / \mathrm{ml})$ in umbilical arterial and venous blood, respectively. Previous experiments of ${ }^{14}(\mathrm{C}$-bicarbonate infusion into the fetus have demonstrated that in the steady state the rate of $\mathrm{CO}$. excretion via the umbilical circulation is equal to the rate of ${ }^{14} \mathrm{CO}_{2}$ production within the fetus (7). Therefore, $r_{(2)}$ represents the rate of tracer leucine decarboxylation within the fetus. This rate may also include decarboxylation of KIC molecules reentering fetal blood after the placental deamination of fetal leucine (6)

The rate at which fetal plasma leucine enters fetal protein synthesis ( ${ }^{\prime \prime} R$, ) was calculated from the equation:

$$
\left.{ }^{1} \text { "u } R_{n}=K_{s} \times(1 . c u)_{p R} / 1440\right)
$$

where $K$, is the fractional synthetic rate per day. I.eupe is the amount of leucine in fetal proteins $(\mu \mathrm{mol})$, and 1440 is the number of $\mathrm{min} / \mathrm{day}$. The fractional rate $K$, was estimated by means of a two step procedure. A first estimate of $k$, was made using the formula:

$$
K_{s}=-t^{-1} \ln \left[1-\left(S \wedge_{p R} / S \Lambda\right)\right]
$$

where $t$ is the total infusion time in dass and $S \Lambda_{P}$ is the specitic activity of leucine in fetal proteins at the end of infusion. I:quation 5 accounts for the backflow of tracer kecine into fetal plasma due to fetal protein degradation (2) and is preterable to the equation that neglects tracer backflow:

$$
K_{s}=1^{-1}\left(S \wedge_{P R} / S A\right)
$$

However, in the 4-h infusion the specific activity of leucine in fetal proteins increased to approximately $3.5 \%$ of the plasma leucine specific activity so that the use of equation 6 would have underestimated $\mathrm{K}$, by only $2 \%$. Both equations 5 and 6 assume that $\mathrm{SA}$ was constant during the infusion. This assumption is not exactly correct because in these experiments the specific activity of plasma leucine attained steady state approximately 30 minutes after the start of the infusion. Therefore, a more retined calculation was made using Swick's equation (10):

$$
\left(S \wedge_{P^{\prime} K} / S \wedge\right)=1-\left[\left(K_{1} c^{K_{1}}\right)-\left(K_{1} e^{K_{1} \cdot 1}\right)\right] /\left(K_{1}-K_{1}\right)
$$


where $\mathrm{K}_{\mathrm{F}}$ is the rate constant with which plasma specific activity attained equilibrium. The $\mathrm{K}_{F}$ constant was estimated by plotting $\ln \left(\mathrm{SA}-\mathrm{SA}_{\mathrm{t}}\right) / \mathrm{SA}$ versus $\mathrm{t}$ for all observations prior to $\mathrm{t}=30$. The estimated value was $110 \mathrm{day}^{-1}$. The $\mathrm{K}_{\mathrm{s}}$ constant was then calculated by an iterative procedure using the value calculated by means of equation 5 as the initial estimate. Since $K_{F}$ is much greater than $\mathrm{K}_{\mathrm{s}}$, this calculation does not require precise knowledge of $K_{F}(10)$. The $K_{s}$ thus estimated was approximately $5 \%$ higher than the $\mathrm{K}_{\mathrm{s}}$ estimated with equation 5 .

The flux of leucine into the placenta from the fetus $\left(R_{p, f}\right)$ was estimated as the difference between $D R$ and the $\left(R_{o x}+{ }^{\text {Leu }} R_{s}\right)$ sum.

Rate of protein synthesis. To estimate rates of fetal protein synthesis from the incorporation of tracer amino acids in fetal proteins, it is necessary to estimate the protein content of the fetus. The grams of protein present in the fetus were estimated in an earlier study from our laboratory (2) as 6.25 times the nitrogen content of the fetal carcass. This calculation assumes an average protein nitrogen content of $16 \%$ and that virtually all of the fetal nitrogen is protein nitrogen. Subsequent data (8) showed that this calculation may overestimate the amino acid content in fetal proteins by as much as $10 \%$. Therefore, in the present study we have calculated the $g$ of protein per $g$ of leucine in the following manner: the total protein amino acid/leucine ratio was determined at different gestational ages from an acid hydrolysis of homogenates of the fetal carcass. This ratio increases with GA (days) according to the regression equation:

( $\mathrm{g}$ total amino acids $) /(\mathrm{g}$ leucine $)=10.7+0.0235 \mathrm{GA}$

This increase is likely to represent changes in the relative amounts of different proteins present in the fetus since there is a marked increase in fetal hydroxyproline content with fetal age indicating an increase in collagen and/or elastin (8). The equation used to calculate protein synthesis rate from the tracer leucine data $\left(\mathrm{PR}_{\mathrm{s}}\right.$, g/day) was:

$\mathrm{PR}_{\mathrm{s}}={ }^{\mathrm{Lcu}} \mathrm{R}_{\mathrm{s}} \times 1440 \times 131.18$

$$
\times 10^{-6}(10.7+0.0235 \mathrm{GA})
$$

where 131.18 is the molecular weight of leucine. To compare protein synthesis rates estimated by the use of tracer leucine with rates previously estimated in our laboratory by the use of tracer lysine (2), the following equation was applied to the lysine data:

$\mathrm{PR}_{\mathrm{s}}={ }^{\mathrm{Lys}} \mathrm{R}_{\mathrm{s}} \times 1440 \times 146.19$

$$
\times 10^{-6}(11.8+0.0210 \mathrm{GA})
$$

where 146.19 is the molecular weight of lysine. The linear regression of the fetal protein amino acids/lysine $(\mathrm{g} / \mathrm{g})$ ratio versus gestational age is encornpassed in the parentheses. All regression analyses were done by the least squares method.

\section{RESULTS}

The 12 fetuses ranged in gestational age from 73 to 88 days. Among fetuses, arterial oxygen saturation ranged between 56 and $75 \%$ (mean $68 \%$ ), umbilical venous oxygen saturation between 86 and 94\% (mean 91\%), and arterial lactate between 0.7 and $1.5 \mathrm{mM}$ (mean $1.1 \mathrm{mM}$ ). Individual fetal and placental weights, umbilical blood flows, and oxygen uptakes were as shown in Table 1. The data in all tables are presented in order of increasing fetal age.

Leucine fluxes. The DR ranged between 3.07 and $9.06 \mu \mathrm{mol} /$ min (Table 2) and was correlated $(r=0.89)$ to $\mathrm{DW}(\mathrm{DR}=1.98$ $+0.077 \mathrm{DW})$. In each fetus the disposal rate of leucine carbon on position one had three major components, namely: the flux into $\mathrm{CO}_{2}$ excretion ( $\mathrm{R}_{\mathrm{ox}}$, range 5.7 to $30.5 \%$ of $\mathrm{DR}$ ), the flux into protein synthesis $\left(R_{s}\right.$, range 22.9 to $52.4 \%$ of $\left.D R\right)$, and a third residual component representing primarily the flux of fetal leucine molecules into placental metabolism $\left(\mathrm{R}_{\mathrm{p}, \mathrm{f}}\right.$, range 21.0 to $64.5 \%$ of DR). The variability of the latter component could be accounted for primarily by individual variability in the relationships of placental and fetal masses. The placental/fetal dry weight ratio ranged between 2.86 and 0.77 (Table 3 ) and was significantly correlated $(r=0.84)$ with the $\mathrm{R}_{\mathrm{p}, \mathrm{f}} / \mathrm{DR}$ ratio (Fig. 1).

There was a strong correlation $(r=0.94)$ between plasma leucine flux into fetal proteins $\left(R_{s}\right)$ and fetal dry weight $\left(R_{s}=\right.$ $-0.125+0.0562 \mathrm{DW})$. The $\mathrm{R}_{\mathrm{s}}$ per $\mathrm{g}$ of fetal dry weight $\left(\mathrm{R}_{\mathrm{s}} / \mathrm{DW}\right.$, mean $\left.0.0534 \pm 0.0021 \mu \mathrm{mol} \cdot \mathrm{min}^{-1} \cdot \mathrm{g}^{-1}\right)$ had a relatively small coefficient of variation $( \pm 13.9 \%)$ and was not significantly correlated $(r=-0.02)$ with plasma leucine concentration. By contrast, the fetal plasma leucine decarboxylation rate per $g$ of dry weight $\left(\mathrm{R}_{\mathrm{ox}} / \mathrm{DW}\right.$, mean $\left.0.0275 \pm 0.0043 \mu \mathrm{mol} \cdot \mathrm{min}^{-1} \cdot \mathrm{g}^{-1}\right)$ had a large coefficient of variation $( \pm 53.8 \%)$ and was significantly correlated $(r=0.63, p<0.05)$ with plasma leucine concentration. Plasma leucine concentration ranged between 0.186 and 0.079 $\mu \mathrm{mol} / \mathrm{ml}$ and had a mean value of $0.122 \pm 0.008 \mu \mathrm{mol} / \mathrm{ml}$.

Fetal protein synthesis. Table 2 presents the fractional rates of plasma leucine flux into the protein leucine pool $\left(\mathrm{K}_{\mathrm{s}}, \mathrm{day}^{-1}\right)$ and the estimated rates of fetal protein synthesis $\left(\mathrm{PR}_{s}, \mathrm{~g} /\right.$ day $)$. The mean $\mathrm{K}_{\mathrm{s}}$ value was $0.216 \pm 0.010 \mathrm{day}^{-1}$. Comparison of the $\mathrm{K}_{\mathrm{s}}$ data in Table 2 with previously measured $K_{s}$ values of leucine and lysine in older fetuses $(2,6)$ showed a significant decline $(r=-0.87)$ of the fractional synthetic rate with fetal age (Fig. 2). The rate of protein synthesis ranged between 2.14 and 11.44 $\mathrm{g} /$ day and was correlated $(r=0.94)$ with dry weight. For the purpose of estimating the allometric relationship between $P_{s}$ and DW, all available data were used in a plot of $1 \mathrm{~g} \mathrm{PR}_{\mathrm{s}}$ versus

Table 1. Fetal age, fetal and placental wt, umbilical blood flow, and fetal oxygen uptake $\left(\dot{V}_{O_{2}}\right)$

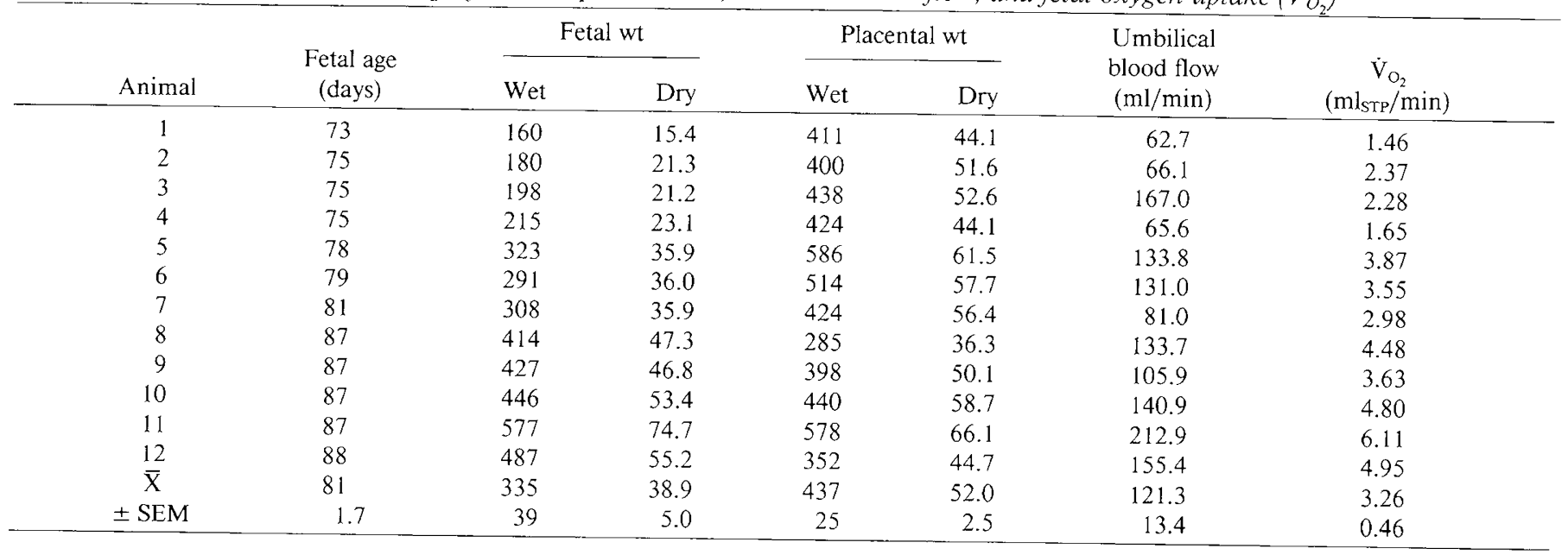


FETAL LEUICINE METABOI.ISM

Table 2. Fetal plasma loucine concentration, D R, $R_{\ldots}$. and $R_{\ldots}, K_{\ldots}, P R$.

\begin{tabular}{|c|c|c|c|c|c|c|}
\hline Animal & $\begin{array}{l}\text { Plasma teucine } \\
\qquad(\mu \mathrm{mol} / \mathrm{ml})\end{array}$ & I)R & $\underset{(\mu \mathrm{mol} / \mathrm{min})}{\mathrm{R}_{11}}$ & $\mathrm{R}_{s}$ & $\begin{array}{c}\mathrm{K} \\
(\text { dar }\end{array}$ & $\begin{array}{c}\text { PR, } \\
\text { (g/day) }\end{array}$ \\
\hline 1 & (0.11.3 & 3.07 & 0.17 & 0.91 & 0.218 & 2.14 \\
\hline 2 & 0.186 & 4.62 & 1.09 & 1.06 & 0.208 & 2.57 \\
\hline 3 & 0.135 & 4.21 & 0.47 & 1.06 & 0.194 & 2.50 \\
\hline 4 & 0.105 & 3.10 & 0.22 & 1.52 & 0.257 & 3.58 \\
\hline 5 & 0.079 & 4.27 & 0.41 & 1.64 & 0.201 & 3.88 \\
\hline 6 & 0.147 & 6.44 & 1.79 & 1.96 & 0.225 & 4.65 \\
\hline 7 & 0.092 & 5.37 & 1.64 & 1.96 & $(0.249)$ & 4.67 \\
\hline 8 & 0.127 & 5.05 & 1.34 & 2.19 & $(0.179$ & 5.27 \\
\hline 9 & 0.126 & 6.83 & 1.20 & 2.66 & 0.222 & 6.40 \\
\hline 10 & 0.105 & 6.42 & 0.86 & 2.79 & 0.21 .3 & 6.72 \\
\hline 11 & 0.128 & 9.06 & 2.41 & 4.75 & 0.275 & 11.44 \\
\hline 12 & 0.120 & 6.18 & 1.46 & 2.22 & 0.155 & 5.35 \\
\hline $\bar{x}$ & 0.122 & 5.39 & 1.09 & 1.89 & 0.216 & 4.93 \\
\hline \pm SEM & 0.0008 & 0.49 & 0.20 & 0.33 & 0.010 & 0.73 \\
\hline
\end{tabular}

Table 3. Lemcinc fluxes $R_{o,}, R_{\mathrm{b}}$, and $R_{p, 2}$ expressed as \% of leucine disposal rate, and leucine fluxe's $R_{o n}$ and $R_{\text {s expressed }}$

\begin{tabular}{|c|c|c|c|c|c|}
\hline & & $r g r$ & al $d r$ & & \\
\hline Animal & $\begin{array}{l}\mathrm{R}_{0, x} \\
(\%)\end{array}$ & $\begin{array}{l}\mathrm{R}_{\mathrm{s}} \\
(\%)\end{array}$ & $\begin{array}{l}\mathrm{R}_{\mathrm{p}, \mathrm{r}} \\
(\%)\end{array}$ & $\begin{array}{l}\mathrm{R}_{\mathrm{in}} / \mathrm{g} \\
(\mu \mathrm{mol} \cdot \min \end{array}$ & $\begin{array}{l}\mathrm{R} / \mathrm{g} \\
\left.{ }^{1} \cdot \mathrm{g}^{-1}\right)\end{array}$ \\
\hline 1 & 5.7 & 29.8 & 64.5 & 0.0113 & 0.0594 \\
\hline 2 & 23.6 & 22.9 & 53.5 & 0.0512 & 0.0512 \\
\hline 3 & 11.0 & 25.2 & 6.3 .8 & 0.0219 & 0.0500 \\
\hline 4 & 7.2 & $49 .(0)$ & 4.3 .8 & 0.00997 & 0.0658 \\
\hline 5 & 9.7 & 38.4 & 51.9 & 0.0115 & 0.0457 \\
\hline 6 & 27.8 & 30.4 & 41.8 & 0.0497 & 0.0544 \\
\hline 7 & 30.5 & 36.5 & 33.0 & 0.0457 & 0.0546 \\
\hline 8 & 26.5 & 43.4 & 30.1 & 0.0283 & 0.0463 \\
\hline ) & 17.6 & 38.9 & 43.5 & 0.0256 & 0.0568 \\
\hline 10 & 13.4 & 4.3 .5 & 43.1 & 0.0161 & 0.0522 \\
\hline 11 & 26.6 & 52.4 & 21.0 & 0.0323 & 0.06 .36 \\
\hline 12 & 23.6 & 35.9 & 40.5 & 0.0264 & $0.04(0) 2$ \\
\hline $\bar{x}$ & 18.6 & 37.2 & 44.2 & 0.0275 & 0.05 .34 \\
\hline SIEM & 2.6 & 2.6 & 3.7 & 0.0043 & 0.0021 \\
\hline
\end{tabular}

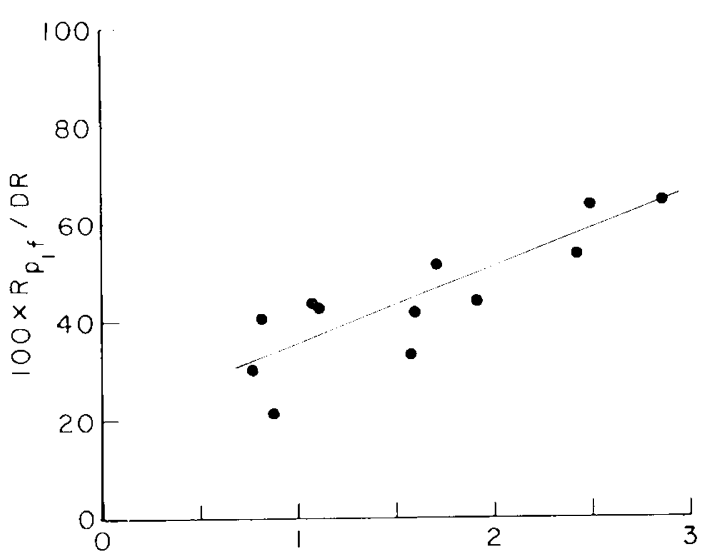

Placenta/Fetus Dry Weight Ratio

Fig. 1. The flux of leucine molecules into the placenta from fetal plasma, expressed as percent of fetal plasma leucine disposal rate is plotted against the placenta/fetus dry weight ratio. Regression line $(r=$ 0.84 ) drawn according to equation: $y=20+15.4 x$.

$1 \mathrm{~g}$ DW (Fig. 3). The slope of the regression equation was less than one (0.754), indicating that over the latter half of intrauterine life the rate of protein synthesis increases less rapidly than fetal mass.

\section{DISCUSSION}

The present study, together with our previous work on the late gestation fetus $(2,6)$, demonstrates that the $\mathrm{K}_{\text {, decreases signifi- }}$

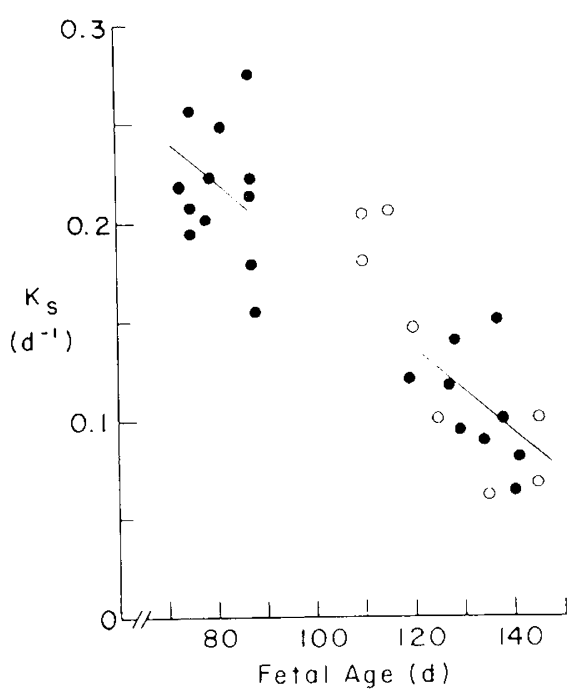

Fig. 2. The $\mathrm{K}_{\mathrm{a}}$ is inversely related to fetal age. Dots indicate rates measured using tracer leucine and open circles indicate rates measured using tracer lysine. Regression line $(r=-0.87)$ drawn according to equation: $y=0.39-0.021 x$.

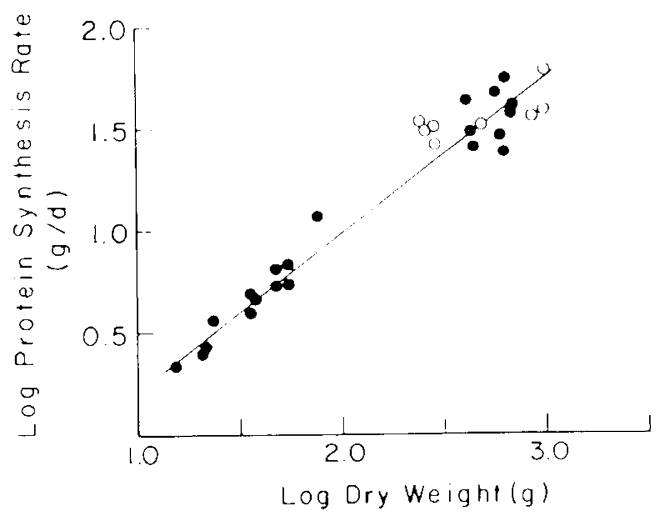

Fig. 3. Log-log plot of fetal protein synthesis rate versus fetal dry weight. Simbols as in Figure 2. Regression line $(r=0.97)$ drawn according to equation: $y=-0.50 .3+0.754 x$.

cantly with fetal age from approximately $23 \%$ per day at midgestation ( 74 day) to less than $10 \%$ per day at term (1 48 day). This decrease is concomitant with a decrease in the $K_{(i}$. In this breed of sheep estimates of $K_{1}$ at mid gestation vary between $13 \%$ per day (5) and $9 \%$ per day (6). whereas in late gestation $\mathrm{K}_{(;}$is approximately $4 \%$ per day (6). 
Protein synthesis includes both protein accretion due to growth and protein turnover due to degradation and resynthesis of existing proteins. Therefore, a relatively high rate of fetal protein synthesis at mid gestation could not have been predicted solely from the higher rate of fetal growth because protein accretion can be increased either by increasing synthesis or by decreasing degradation. The higher value of $\mathrm{K}_{\mathrm{s}}$ with respect to $\mathrm{K}_{\mathrm{G}}$ shows that protein turnover is a quantitatively important component of fetal protein synthesis.

We have previously demonstrated that there is a decrease in the oxygen consumption rate per unit dry weight as the fetus grows to maturity (4). This study demonstrated that fetal oxygen consumption $\left(\dot{\mathrm{V}}_{\mathrm{O}_{2}}\right.$, liter $\left.\mathrm{day}^{-1}\right)$ is related to $\mathrm{DW}(\mathrm{g})$ by the allometric equation:

$$
\dot{\mathrm{V}}_{\mathrm{O}_{2}}=0.323 \mathrm{DW}^{0.729}
$$

Since a decrease in protein synthetic rate represents a decline in energy requirements, it is interesting to compare the changes in fetal protein synthesis and oxygen consumption rate that occur during fetal growth. The present study (see Fig. 3) shows the allometric relation between rate of protein synthesis $\left(\mathrm{PR}_{s}, \mathrm{~g}\right.$ day $^{-1}$ ) and dry weight to be:

$$
\mathrm{PR}_{\mathrm{s}}=0.314 \mathrm{DW}^{0.754}
$$

The similarity of the two exponents $(0.729$ versus 0.754$)$ indicates that protein synthesis and energy metabolism decelerate during growth at approximately the same rate so that the $\mathrm{PR}_{\mathrm{s}} / \dot{\mathrm{V}}_{\mathrm{O}_{2}}$ ratio tends to remain constant. According to equations 11 and 12 , as the fetus grows from 25 to $650 \mathrm{~g} \mathrm{DW}$, the $\mathrm{PR}_{\mathrm{s}} / \dot{\mathrm{V}}_{\mathrm{O}_{2}}$ ratio only changes from 1.05 to $1.14 \mathrm{~g} /$ liter. Given that the synthesis of 1 $\mathrm{g}$ of protein requires the expenditure of approximately $0.8 \mathrm{kcal}$ (11) and that the caloric equivalent of oxygen in the lamb fetus is approximately $4.9 \mathrm{kcal} /$ liter of oxygen (12), we can estimate from the $\mathrm{PR}_{\mathrm{s}} / \dot{\mathrm{V}}_{\mathrm{O}_{2}}$ ratio that the energy cost of protein synthesis during the latter half of fetal life represents approximately $18 \%$ of fetal oxidative metabolism. This estimate is remarkably similar to the figure (17\%) calculated by Garlick et al. (13) for the cost of protein synthesis in pigs, rats and humans.

It is important to note, however, that we base this comparison on data obtained by similar methods, namely, measurements of tracer amino acid flux from circulating plasma into tissue proteins. These methods tend to underestimate the rate of protein synthesis by the whole organism for two main reasons: 1) some amino acid molecules originating from protein degradation reenter protein synthesis without cycling through the general circulation, and 2) the synthetic rate of proteins with high turnover rates is underestimated by methods that measure protein specific activity after several hours of tracer infusion $(10,14)$. Although the entry rate of amino acids from the vascular compartment into body proteins does not represent total entry rate, measurements of plasma amino acid fluxes into proteins in postnatal life have demonstrated conclusively that the weight specific protein synthetic rate declines as body size increases and that this decline is proportional to the decline in weight specific oxygen consumption (14). It is apparent from our results that a similar relationship exists in prenatal life. To demonstrate this relationship we used fetal dry weight as the basis for comparison. During fetal growth there is a considerable decrease in percent fetal water content which makes fetal wet weight an unreliable basis for comparing metabolic requirements at different stages of fetal growth (4).

Our results demonstrate that there is a relatively rapid rate of leucine oxidation in the immature fetus. In the present study (mean fetal age $81 \pm 1.7$ day) the mean rate of fetal leucine oxidation per gram dry weight was significantly higher than in a group of older fetuses (6) with mean age $133 \pm 3.3$ day $(0.0275$ versus $\left.0.0110 \mu \mathrm{mol} \cdot \mathrm{min}^{-1} \cdot \mathrm{g}^{-1}, p<0.02\right)$. The higher oxidation rate occurred despite a lower plasma leucine concentration in the younger fetuses $(0.122$ versus $0.167 \mu \mathrm{mol} / \mathrm{ml}, p<0.05)$. This finding may simply represent another aspect of the high metabolic rate of the immature fetus. Another possibility, however, is that the placenta stimulates the catabolism of leucine by deaminating fetal leucine and by returning to the fetus KIC molecules which are then oxidized. Although the interaction of placental and fetal metabolism needs to be considered at all stages of fetal development, it is likely to be particularly important at midgestation when the mass of placental cotyledons exceeds fetal mass by a large margin (Table 3 ). Since leucine is an essential amino acid, its net flux is from placenta to fetus (15). Tracer leucine data have demonstrated, however, that this net flux is the algebraic sum of two large and opposite unidirectional fluxes that continuously exchange leucine molecules between placenta and fetus (6). When the placenta is large in relation to the fetus, the placental-fetal exchange represents the largest component of fetal leucine disposal rate (Fig. 1).

The placental contribution to disposal of fetal amino acids may explain in part why some estimates of fetal protein synthesis have been surprisingly high. For example, Schaefer and Krishnamurti (3) studied tyrosine metabolism in the late gestation fetal lamb and concluded that the fetus synthesizes proteins at the rate of $63 \mathrm{~g} / \mathrm{day} / \mathrm{kg}$ wet weight. This rate is approximately four to six times the value obtained by us using either tracer lysine (2) or tracer leucine (6). Inspection of their experimental data shows that after $8 \mathrm{~h}$ of fetal infusion with tracer tyrosine the protein bound/free plasma specific activity ratio in different organs ranged from 3.1 to $1.8 \%$. Calculation of $\mathrm{K}_{\mathrm{s}}$ values by means of these figures would give results similar to those obtained in our laboratory. However, the calculation of fetal whole body protein synthetic rate was based on a two-pool model of fetalmaternal tyrosine exchange that corrects for the small flux of fetal amino acid into the mother but does not correct for the potentially large flux of tyrosine into the placenta. Estimates of placental protein synthesis rate in sheep have yielded relatively high values (16).

\section{REFERENCES}

1. Faichney GJ 1981 Amino acid utilisation by the foetal lamb. Proc Nutr Soc $6: 48-53$

2. Meier PR, Peterson RG, Bonds DR, Meschia G, Battaglia FC 1981 Rates of protein synthesis and turnover in fetal life. Am J Physiol 240:E320-E324

3. Schaefer AL, Krishnamurti CR 1984 Whole body and tissue fractional protein synthesis in the ovine fetus in ttero. Br J Nutr 52:359-369

4. Bell AW, Battaglia FC, Makowski EL, Meschia G 1985 Relationship between metabolic rate and body size in fetal life. Biol Neonate 47:120-123

5. Bell AW, Kennaugh JM. Battaglia FC, Makowski EL, Meschia G 1986 Metabolic and circulatory studies of the fetal lambs at mid gestation. Am J Physiol
250:E538-E544

6. van Veen LCP, Meschia G, Hay WW Jr, Battaglia FC 1987 Leucine disposal and oxidation rates in the fetal lamb. Metabolism 36:48-53

7. van Veen LCP, Hay WW Jr, Battaglia FC, Meschia G 1984 Fetal $\mathrm{CO}_{2}$ kinetics. J Dev Physiol 6:359-365

8. Meier PR, Teng C, Battaglia FC, Meschia G 1981 The rate of amino acid nitrogen and total nitrogen accumulation in the fetal lamb. Proc Soc Exp Biol Med 16:463-468

9. Meschia G, Cotter JR, Makowski EL, Barron DH 1967 Simultaneous measurement of uterine and umbilical blood flows and oxygen uptakes. Q J Exp Physiol 52:1-18

10. Zak R, Martin AF, Blough R 1979 Assessment of protein turnover by use of radioisotopic tracers. Physiol Rev 59:407-447 11. Millward DJ, Garlick PJ 1976 The energy cost of growth. Proc Nutr Soc
35:339-349 12. Battaglia FC, Meschia G 1978 Principal substrates of fetal metabolism. Physiol
Rev 58:499-527

13. Garlick PJ, Burk TL, Swick RW 1976 Protein synthesis and RNA in tissues of the pig. Am J Physiol 230:1 108-1112

14. Waterlow JC, Garlick PJ, Millward DJ 1978 Protein Turnover in Mammalian Tissues and in the Whole Body. Elsevier/North Holland Biomedical Press, Amsterdam

15. Lemons JA, Adcock EW III, Jones MD Jr, Naughton MA, Meschia G, Battaglia FC 1976 Umbilical uptake of amino acids in the unstressed fetal lambs. $J$ Clin Invest 58:1428-1434 16. Young M, Stern MDR, Horn G, Noakes DE 1982 Protein synthesis in the
sheep placenta in vivo: the influence of insulin. Placenta $3: 159-164$ 